INTERNATIONAL JOURNAL OF INNOVATION IN ENTERPRISE SYSTEIM

Journal homepage: https://ijies.sie.telkomuniversity.ac.id e-ISSN: 2580-3050, DOI: https://doi.org/10.25124/ijies.v6i01.127

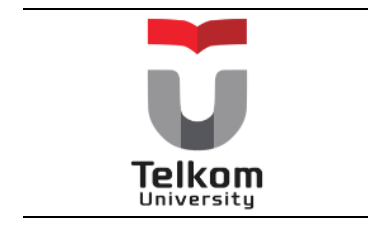

\title{
Public Policy and Financial Regulation in Housing Sector (Case Study: One Million Houses and KPR FLPP)
}

Maria Dellarosawati Idawicaksakti ${ }^{1 *}$, Monica Dianrosawati Itaratnasari ${ }^{2}$, Raden Aswin Rahadi ${ }^{3}$

${ }^{1}$ School of Industrial and System Engineering

Telkom University, Bandung, Indonesia

mariadellarosawati@telkomuniversity.ac.id

${ }^{2}$ School of Business and Management

Institut Teknologi Bandung, Bandung, Indonesia

itaratnasari.monica@gmail.com

${ }^{3}$ School of Business and Management

Institut Teknologi Bandung, Bandung, Indonesia

aswin.rahadi@sbm-itb.ac.id

*mariadellarosawati@telkomuniversity.ac.id

\section{ARTICLE INFO}

Article history:

Received 04 March 2021

Accepted 30 August 2021

Published 31 January 2022

\section{ABSTRACT IN ENGLISH}

During Jokowi's tenure, a lot of programs and policies that focusing on housing sector were built by him. Package of Economic Policy XIII is one of many policy's package that Jokowi develop for managed housing of people who have low income (MBR) with target that chosen is built one million houses. The lack of availability of housing for low-income people, is one of the reasons for the policy package. In this research, author used qualitative method to analyst the phenomenon. The results of this study are the high rate of housing backlogs, the difficulty of obtaining housing at affordable prices, and discussing KPR schemes in Indonesia. The existence of these government programs does not significantly eliminate the phenomenon of housing a backlog. In addition, the existence of the program must be accompanied by high supervision from the government and accompanied by laws that bind violators.

Keywords:

Housing Backlog; KPR

This is an open-access article under the CC BY-NC-SA license.

FLPP; Mortgage; One

Million Housing Program;

Package of Economic Policy

XIII

\section{INTRODUCTION}

Economic growth in Indonesia during Joko Widodo's (Jokowi) government is always increasing. Based on data that World Bank published (2018), Gross Domestic Product (GDP) was showing the positive trend or increasing from $5.007 \%$ in 2014 to $5.068 \%$ in 2017. Even the GDP was declining in 2015 into $4.876 \%$ (amount of $0.131 \%$ compared to last year). That caused of economic of scale in Indonesia always growing. However, GDP Indonesia in 2014 was decrease (recession) compared to 2013 in amount of $0.6 \%$ [1]. 


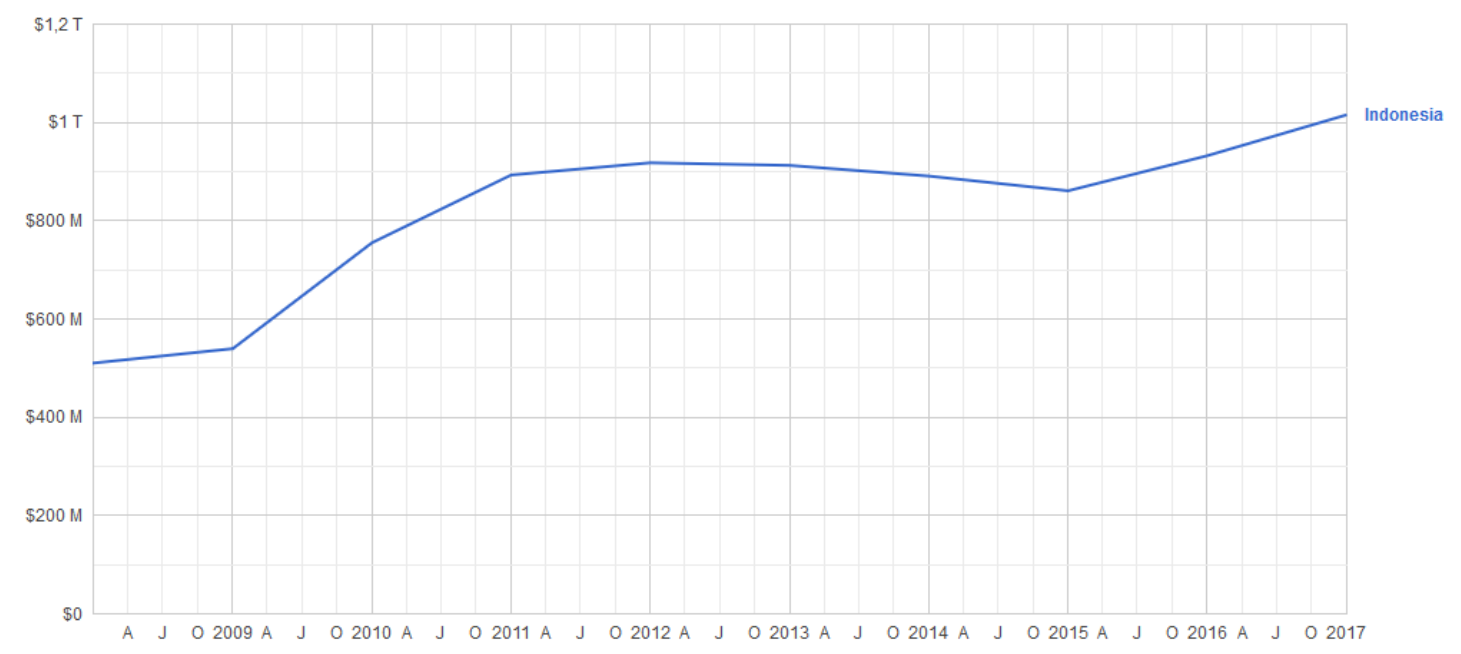

Figure 1 - Indonesia's GDP (2008 - 2017) [2]

National Program for Building One Million Houses are develop based on housing backlog phenomena, which tell us about gap between needs and availability of houses in Indonesia. Based on Badan Pusat Stastik (BPS) in 2015, there are still $17.3 \%$ or around 11.8 million households living in non-owned dwellings (rent, contracts, hitchhiking, official housing, or none). One of the main reasons that Indonesian people are reluctant to own their own houses is the large amount of construction and licensing costs that are time-consuming and not time-consuming.

That subsidy delivers in early 2015 until 2018. That subsidy delivers via Housing Costing Liquidity Facility (FLPP) and Interest Difference Subsidies (SSB) which is 7\% in every subsidy. That subsidy make community only needs to pay interest of Credit of Housing Ownership (KPR) amount of 4-5\%. One million houses that are implemented during Jokowi's tenure make housing backlog in Indonesia reduce by 3.2-million-unit houses (Medcom.id, 2018). Moreover, Jokowi also explained some obstacle that face by housing sector during his tenure. That obstacle includes: legal, lack of land, and spatial planning (including infrastructure).

Based on explaining from minister of Pekerjaan Umum dan Perumahan Rakyat (PUPR) - Basuki Hadimuljono, in addition to overcome the existing obstacles, PUPR also must prepare plans for resolve that obstacle. Basuki said, PUPR have some of resolve's plans, consist of regulation, revitalization of suburban infrastructure, and also prepare financial scheme (Katadata, 2018). Financial scheme or providing subsidies are proposed to reach the society who do not have regular income, so they can still have own house. Moreover, the main problem that constraint National Program for Building One Million Houses are the higher land prices, especially land that increasingly close to the Central Business District (CBD). In other hand, suburban infrastructure is usually inadequate and also become a main focus of PUPR's ministry now.

Housing and settlements have a strategic role in shaping the character and personality of the nation, because housing and settlements reflect the family and social life of household members in the houseThis makes the need for decent housing and its facilities and infrastructure a basic requirement of every human being that will continue to develop in accordance with the stages and life cycles. Houses are basic needs that must be owned by a family or individual. However, the high price of housing is not comparable to the income received by most people in Indonesia. Figure 2 shows property price index in Indonesia from 2016 - 2019. The trend shown positive trends, this indicates that house prices from year to year always increase. 


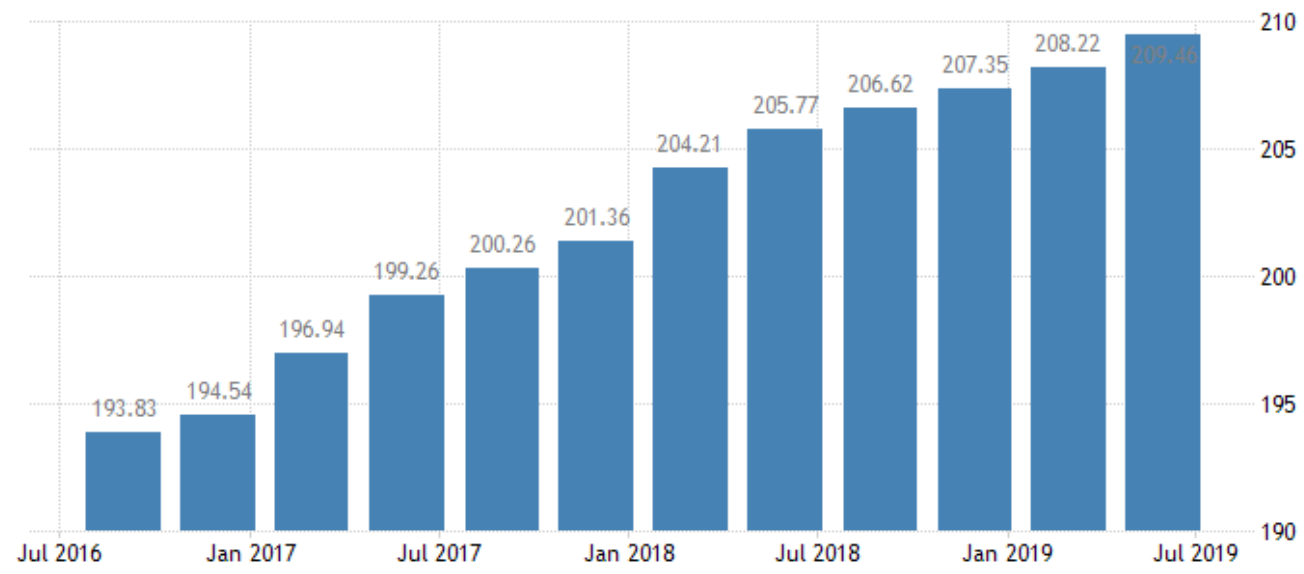

Figure 2 - Indonesia's Property Price Index (2016 - 2019) [3]

\section{METHOD}

The research framework can be concluded for this research. Starting from PESTEL analysis about the Indonesian housing sector. From the results of PESTEL, it is taken a phenomenon that is emerging, namely the housing backlog. The method used to analyze the housing backlog is Market Data Approach. This method is used to compare results from before and after government regulations. In addition, a literature study was conducted to find out the impacts produced by the Package of Economic Policy XIII. After the two methods are carried out, it is hoped that government regulations will emerge better than the Package of Economic Policy XIII, especially for policies housing mortages. The research framework can be seen in Figure 2.

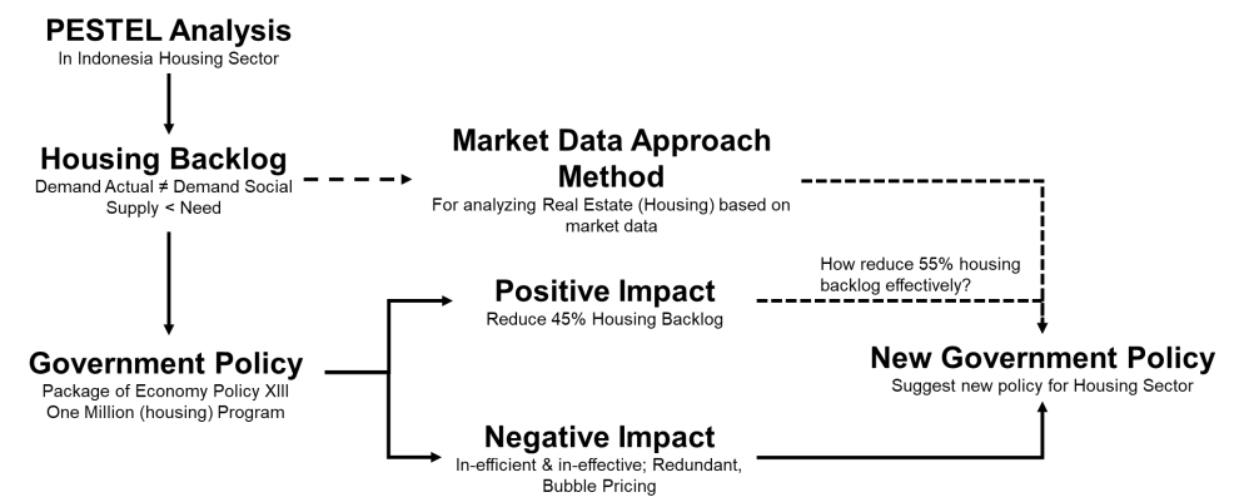

Figure 3 - Research Framework for Housing Backlog in Indonesia

The research method is basically a scientific way to obtain data with specific purposes and uses. Based on this there are four key words that need to be considered, namely the scientific method, data, purpose and usability. This research report discusses phenomena of housing sector in Indonesia and suggestion for new government policy of housing sector in Joko Widodo's tenure The method used is descriptive qualitative method.

According to Sukmadinata (2009), qualitative research is research that is used to describe and analyze phenomena, events, social activities, attitudes, beliefs, perceptions, and people individually or in groups. Qualitative descriptive in this research is used to develop theories that are built through data obtained in the field and interview. The qualitative method of the researcher at the initial stage is exploring, then collecting in-depth data (qualitative data), one-on-one interview, case study research, and process of observation to reporting.

To conduct a one-on-one interview, the researcher formulates some basic questions that will be asked by the respondent. This collection of questions is called the interview protocol. The designed Interview protocol is divided into five major sections. Preparation of these questions is based on the results of existing literature and several phenomena that were raised in the previous chapter. Table 1. is an interview protocol designed by author. 
Table 1 - Interview Protocol

\begin{tabular}{ll}
\hline Part I - Respondent Demographic \\
\hline 1 & Institution: \\
2 & Expert of: \\
3 & Experience: \\
4 & Profession \\
\hline Part II - Respondent Preference (Package Economics Policy XIII and one million houses project) \\
\hline 1 & What are the current conditions regarding housing in Indonesia? \\
2 & What influences regulation in the housing sector? Especially the issue of Housing Backlog? \\
3 & Has the government program significantly surpassed the Housing Backlog? (in this case for residents who \\
\hline Part III - Housing Market in Indonesia \\
\hline 1 & What is the condition of the housing sector supply and demand in Indonesia? \\
2 & Are the market prices of the housing sector in accordance with economic conditions in Indonesia? \\
3 & Do existing government regulations and programs improve the condition of the housing market in Indonesia? \\
\hline Part IV - Mortgages Awareness \\
\hline 1 & In your opinion, are financial regulations for the housing sector sufficient? \\
2 & What are the weaknesses and strengths of the KPR system in Indonesia? \\
3 & How big is the influence of KPR on housing demand in Indonesia? \\
\hline Part V - Valuation of Thousand Housing Program in Joko Widodo's Tenure \\
\hline 1 & In your opinion, is this program right on target? \\
2 & Are there suggestions for improving this program?
\end{tabular}

\section{RESULT AND DISCUSSION}

Based on the results of data collection by conducting interviews and literature studies. The author divides the results of the data into several analysis angles from the results of existing data. For data obtained from interviews, the authors divided into several groups of speakers. The resource group includes consultants, government, academics and practitioners, as well as developers. The following will explain the data from the interview based on the group of speakers.

\subsection{Government (Ministry of PUPR)}

Based on the interview protocol discussed in the previous chapter. The author conducted interviews to obtain data in accordance with the interview protocol that had previously been prepared. Respondents interviewed by the author came from the government division. The government sector in question is the Office of Public Works and Public Housing (Pekerjaan Umum dan Perumahaan Rakyat or PUPR). Respondent A who was interviewed had a profession as an assistant technician in the housing sector and had worked in the job for eight years.

Respondent A explained about the latest conditions regarding housing in Indonesia. According to him, all arrangements and control of the housing sector are in the hands of the government. This makes the government the main holder of the housing market. However, this condition does not affect prices in the housing sector. Prices in the housing sector are affected by supply and demand in the sector. Often the housing offered is too high to impact over supply in the housing sector. Over supply of housing products are not uncommon because prices offered by developers are too high, so people are reluctant to buy them even if they need them. The high price of housing products is also a problem for young couples to get their first home. The difficulty of getting the first house for some community groups has led to an increase in the number of housing backlogs in Indonesia.

Respondent A also explained about the influence of regulation in the housing sector to overcome the problem of housing a backlog. The main influences that occur in Indonesia's housing sector are developers in the housing sector. Competition between developers results in varied housing product prices. This varied market price has a tendency to increase following the trend of housing product supply. However, by mid-2019 the price of housing products has decreased. This was also supported by the statement presented by Muamar (2019), that the decline in housing product prices was due to the high mortgage rates in Indonesia, taxes to the price of building materials. In addition, the housing product offer price is not in accordance with the people's purchasing power, so the demand for housing with the offer of housing products has never met. Figure 3. shows the percentage of Indonesia's houses price growth from July 2016 to January 2019. 


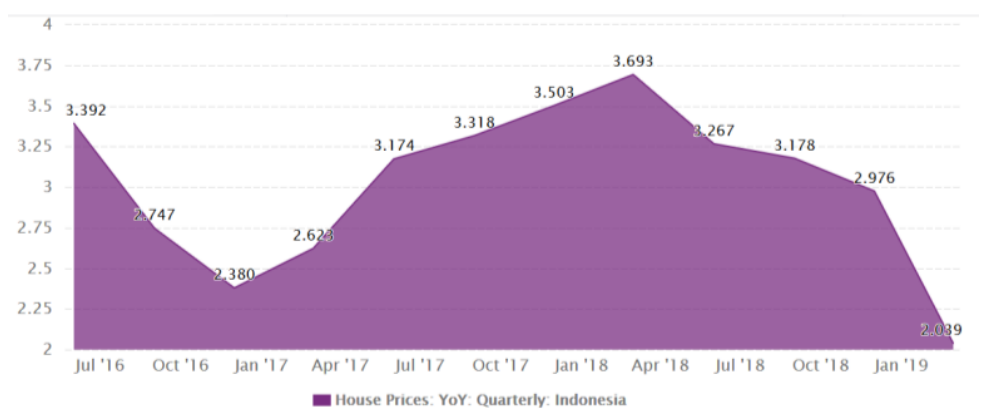

Figure 4 - Indonesia's Houses Price Growth from July 2016 to January 2019 [9]

There is a government program implemented to facilitate low income communities to get subsidies in the housing sector. The program includes a one million houses program, package of economic policy XIII, and providing subsidized KPR. However, the regulations issued do not yet have clear legal rules and bind those who carry them out. Not infrequently also those who violate also the big developers who want to reap the benefits to the consumers who do not know the basic rules regarding buying and selling for housing products. On the other hand, according to Respondent A, the program of one million houses issued by the government has indeed reached the target, but the target set at the beginning has not been reached. This Respondent A explained because there were still a lot of housing products that were built only for the middle to upper class community, causing the middle to lower class people still having difficulty to obtain housing products based on their budget.

\subsection{Academincs and Practitioners}

Respondent B is a respondent from a group of academics and practitioners. Respondent B has been a teacher and analyst since 1995. He teaches at ITB and becomes an expert in housing sector analyst at PUPR. According to Respondent B, housing conditions in Indonesia for housing offers cannot compensate for the number of requests for existing housing products. In addition, the latest problem in the housing sector is the large number of millennials who cannot buy property in the city center. This causes the purchasing power of the housing sector to decline, and has an impact on the Indonesian economy. Figure 4. showing GDP growth in Indonesia in 2009 - 2018. It can be seen that there has been a decline from 2012 - 2016. In 2017 there has been an increase even though it is still below the BI average.

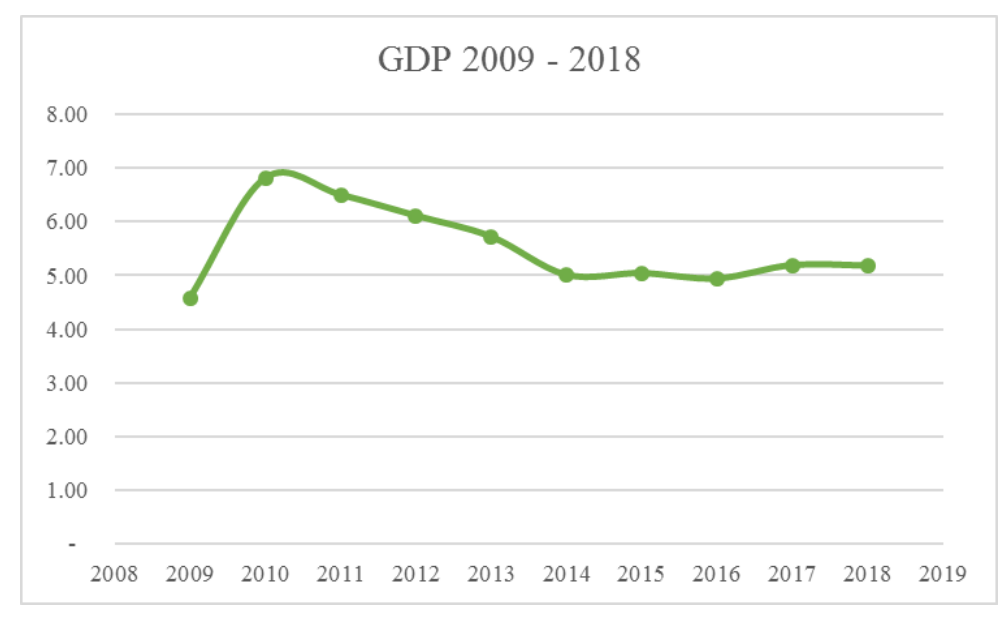

Figure 5 - Indonesia's GDP (2009 - 2019) [4]

Respondent B explained that the stable GDP growth at 5\% and BI interest rates remained at $6 \%$, this made a benchmark that Indonesian people began to increase their consumption. The need for housing increased along with the level of consumption which also increased, making the one million house program in Joko Widodo's tenure to be realized. However, according to Respondent B the program was not on target because many of the people who already owned homes bought subsidized houses to be used as investments. Lack of supervision and binding laws make this happen.

The phenomenon of bubble pricing on the housing sector was also mentioned by Respondent B. This phenomenon can occur if the demand conditions in a market exceed its supply. Respondent B explained, economic conditions in Indonesia tend to be positive, but demand for high housing products creates excess demand for housing. This condition causes prices for automatic product housing to increase. Many factors cause the price of housing products to increase. 
According to Azhar (2017), there are several factors that influence house prices, including location, accessibility, mortgage rates and the conditions of the housing product offered [5].

The existence of a mortgage program helps the community to get a home by way of credit. But not infrequently the interest offered by various banks is different. This causes the price of a house to be many times more expensive than paying directly to the developer. On the other hand, the existence of a mortgage program increases people's purchasing power to buy a house. Especially for subsidized mortgages, the government issues special interest rates that will not change during the installment period. Data released by Bank Tabungan Negara (2019), states that the interest rate for subsidized housing loans is $5 \%$ with a down payment of $1 \%$. [6]

\subsection{Consultant}

There were two respondents from the consultant group interviewed by the author. Respondent $\mathrm{C}$ was the first respondent to be interviewed. Respondent $\mathrm{C}$ is a respondent who comes from renowned consultants in Indonesia. Respondent $\mathrm{C}$ is a consultant focusing on the property sector. He has four years of work experience at the advisory service division and has a position as assistant manager for the division.

According to Respondent $\mathrm{C}$, housing conditions in Indonesia are still mostly concentrated in big cities that have quite good economies. But if you look at housing needs in urban areas, especially Jakarta, needs are still high but high land prices make consumers tend to choose houses in suburbs such as Tangerang and Bekasi or apartments in the city center as an alternative place to live. The price of land and units in several locations on the outskirts of Jakarta has already moved quite high which has caused a large number of unsold house stocks. However, landed houses are still easier to sell than apartments because some people are still not accustomed to buying and living in apartments, especially because ownership status and costs incurred are greater than buying landed houses.

In addition, Respondent C said that regulations related to LTV (Loan to Value) and interest rates were quite influential for the current housing sector, although it seems that economic factors are more influential. In terms of commercial housing, developers currently tend to issue small type houses at a price of one billion rupiah - two billion rupiah. This price range is most quickly absorbed by the market with a large number of units in each development. Government regulations related to LTV do not seem to have helped the absorption of the current housing market. While interest rates play a greater role in terms of housing absorption. This is because the majority of housing buyers use mortgages as a payment method compared to developer installments.

Respondent C's statement was also supported by research conducted by the SMF Research Team (2015), they explained the condition of mortgage growth after the implementation of the relaxation of LTV provisions can be seen in the Figure 16. A month after it was established, the growth of mortgages gradually began to increase. This was seen at the beginning of the second quarter of 2015 after the implementation of the policy. It can be seen in December 2015 that mortgage growth grew by $7.72 \%$ yoy or $1.09 \%$ mom. However, it can also be seen in the Figure 6 that the growth that occurred was not as significant as expected, this proves that the LTV policy is not the only thing that affects the increase in outstanding KPR. The benchmark interest rate and economic growth are considered to influence, because of the expected performance in 2016, supported by conducive macroeconomic conditions and monetary policy, mortgage growth will increase.

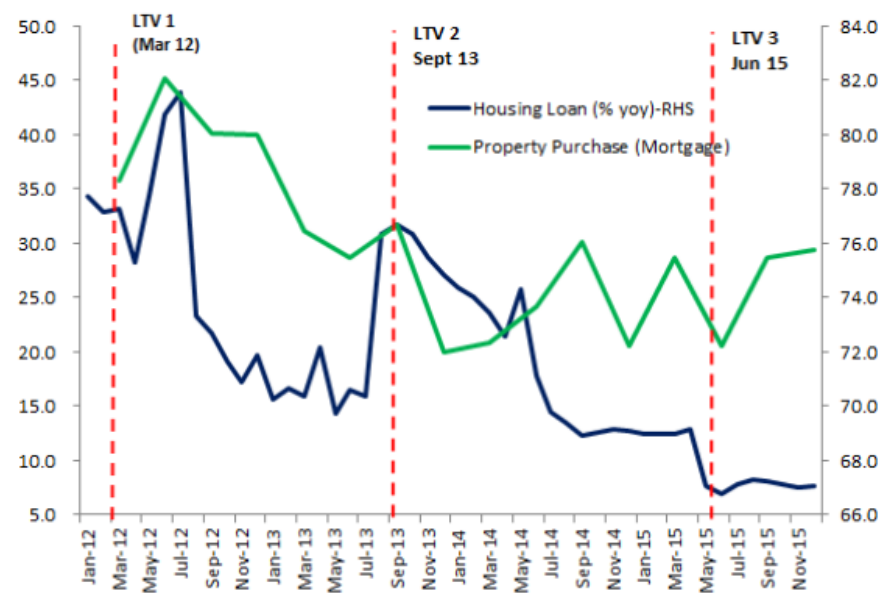

Figure 6 - Growth of KPR and LTV [4]

Regarding the issue of housing needs, Respondent $\mathrm{C}$ also explained that several locations had been declared by the government to make cheap housing or subsidies. Some TOD areas or transit-oriented development where this region is connected with mass transportation mode requires developers to sell subsidy units up to $40 \%$ of the total units sold. 
This is to reduce housing needs, especially for low income group (Masyarakat Berpenghasilan Rendah or "MBR") where these units are sold at special prices with applicable terms and conditions.

On the other hand, housing supply tends to be more than the demand. At present the absorption of houses tends to slow down due to the national and global economy, so that houses with more than two billion rupiah are absorbed less. Many developers have finally launched small type houses to meet current housing needs. In addition, the current price increases tend to be too high, not going straight with the ability of consumers. For some housing in the suburbs of Jakarta, the majority are still bought by investors who expect capital gains. Later it was seen that some developers began braking to launch new products and focus on selling units that have not been absorbed. In some regions that are highly dependent on the mining sector such as Kalimantan, there is a huge oversupply in the area due to the decline in people's purchasing power, so that the absorption of housing there has dropped dramatically.

The government's role in overcoming housing problems according to Respondent $\mathrm{C}$ has been quite good. However, it is often hampered by economic pressures that occur in foreign markets. This economic pressure creates negative perceptions for the domestic economy and impacts on several industrial sectors which impact on declining purchasing power. Figure 6. explained about the growth of KPR and KPA loans, construction, and real estate from 2014 - 2018. Between 2017 - 2018, real estate loans are under KPR. This proves that cheap and subsidized housing is still an attractive offer for people who do not have their first home.

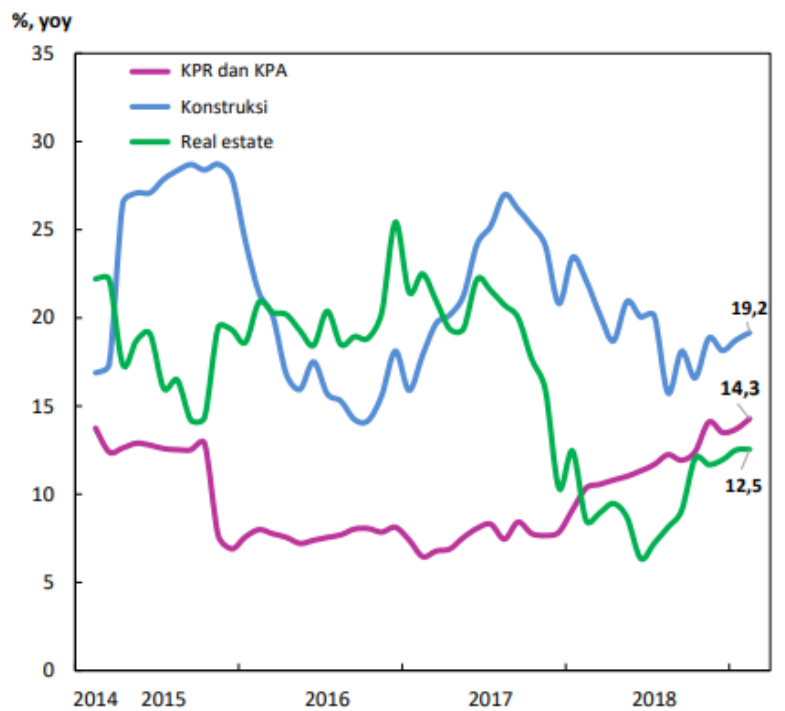

Figure 7 - Growth of KPR / KPA, Construction, and Real Estate Loans (2014 - 2018) [4]

Government programs that build housing subsidies should be accompanied by the provision of good facilities and infrastructure to attract buyers. Some subsidized housing areas are located very far from the economic center so buyers do not glance at the subsidized house and prefer to rent a house close to their workplace. In addition, taxes arising from home buying and selling transactions are also too many and tend to vary.

Respondent $\mathrm{C}$ also mentioned financial regulation in the housing sector. According to him, the regulations set by the government are quite good, but Indonesia's current economic condition causes interest rates to continue to stay at $6 \%$ and it is difficult to go down again. In addition, mortgage interest in Indonesia itself has a degree of flexibility. The weakness according to Respondent $\mathrm{C}$ is high floating interest. Many people are tempted by fixed interest at the beginning of the tenor, even though the floating interest rate is high, it depends on each bank issuing a mortgage. In addition, the costs incurred for issuing mortgages are too much and burdensome to consumers, especially those with limited income. On the other hand, the strength possessed by KPR is that screening for KPR applicants is good enough to reduce the potential for default due to excessive mortgage payments. The government also provides a special rate for subsidized housing issued by state banks.

Not much different from Respondent C, Respondent D also explained almost the same thing. Respondent D comes from one of the property consultants in Indonesia. He has more than twelve years of experience in the property industry and has a profession as a consultant. Limited land, high number of backlogs, and affordability in the housing sector are the conditions of the housing sector in Indonesia according to Respondent D. In addition, according to Respondent D, there are several parties that influence the housing sector. Among them are government initiatives and law enforcement; participation of SMEs, private developers, and investors; and also conducive economy, political, and investment climate.

The high rate of housing backlogs in Indonesia has an impact on the difficulty of the government and all stakeholders in the property sector to reduce this figure. It takes a long time to reduce the number of housing backlogs in Indonesia. 
Especially with the condition of inefficient supply and demand for housing in Indonesia. The high demand for housing in Indonesia is not directly proportional to the housing product offered especially for the middle-low population. In addition, according to Respondent $\mathrm{D}$, he said he could not generalize market prices from the housing sector. There are so many factors that determine the price of housing. Each region has a different market price due to location, character, etc. But in some regions in Indonesia, housing prices have indeed increased significantly, especially in large cities in strategic locations. Economic conditions have helped the growth of the property sector in recent years. Positive economic growth, controlled inflation, and key interest rates, as well as infrastructure development, have helped increase housing demand, which has also increased prices (due to increased demand).

\subsection{Developer}

Respondent E came from one of the developers in Indonesia. Has one year experience as a business developer. Respondent E said that the housing conditions in Indonesia are the high demand for homes for middle and lower groups which is still the cause of the high number of backlogs in Indonesia. In addition, the still high price of housing units makes it difficult for middle-low groups to get decent housing. However, with the emergence of a subsidized mortgage system, it has an impact on the ease of the middle-income community to get a decent home.

In terms of financial regulation, Respondent $\mathrm{E}$ said that the regulation provided by the government was quite adequate with the KPR scheme. In addition, the scheme is considered to be able to avoid the economic crisis. Respondent E also explained that the mortgage scheme has advantages and disadvantages. The advantage of KPR is that it makes it easy for credit requesters to get their homes with not large capital. On the other hand, the weakness of KPR is when a home buyer has completed the installments of the house price paid as if it were more expensive many times over. Although KPR in Indonesia are very popular, the fact is that the purchasing power of Indonesian people is still low. Therefore, mortgages provide a long tenor so that people can buy houses in installments according to their income with a adjusted credit period.

From the explanation of Respondent E, he explained about the high demand for small type houses in Indonesia. Figure 7. explain about the annual growth of property sales in Indonesia from 2017 - 2019. It can be seen that the growth of small type houses has increased very high in mid-2018 and then declined at the end of 2018 and increased again in early 2019. It can be seen also that type houses small growth is not negative such as medium and large type houses.

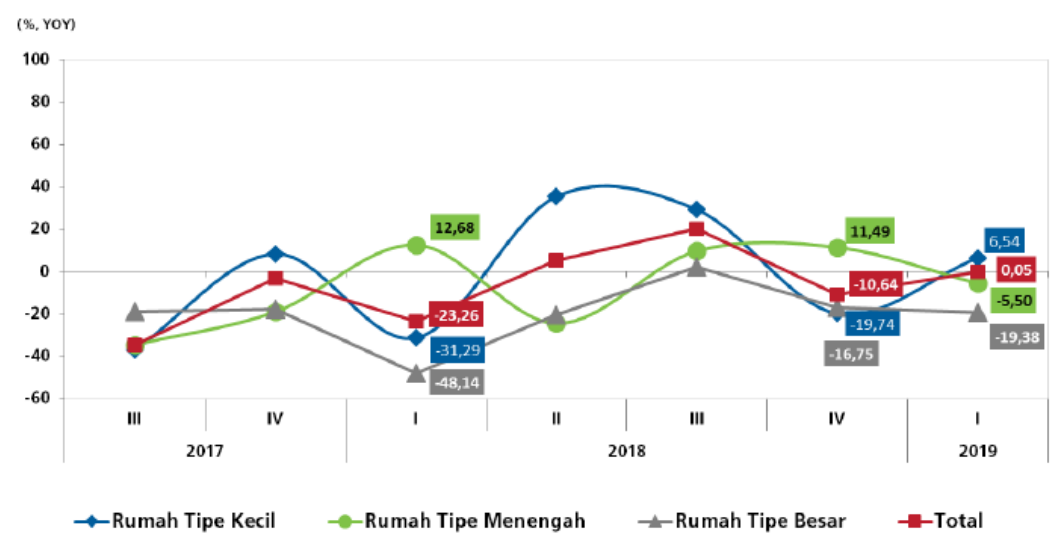

Figure 8 - Annual Growth of Home Sales (\% YoY) [7]

From the results of interviews conducted, the program for building one million houses in Jokowi's tenure has been realized. The purpose of the realization of this program is that there have been 1,114,608 housing units built in 2018 and the percentage for MBR is $69 \%$ of total development (Prabowo, 2019). Figure 8. shows the growth of residential property price index in 2014 - 2018 in Jabodetabek and Banten. It can be seen that the ratio for small type houses has a high average price ratio compared to small, medium and big. This proves that the price for small house types increases but the amount offered can be said to be fixed or declining.

\begin{tabular}{cccccc}
\hline & 2014 & 2015 & 2016 & 2017 & 2018 \\
\hline JABODEBEK-BANTEN & & & & & \\
SMALL & 6.58 & 4.76 & 2.23 & 7.49 & 4.05 \\
MEDIUM & 5.28 & 2.76 & 0.81 & 2.95 & 3.74 \\
BIG & 3.34 & 0.91 & 0.11 & 1.08 & 1.38 \\
\hline TOTAL & 5.06 & 2.81 & 1.04 & 3.83 & 3.05 \\
\hline
\end{tabular}

Table 2 - Growth of Residential Property Price Index (2014 - 2018) [7] 
The high ratio of prices of small type houses in Jabodetabek and Banten shows that demand for houses in the center of Central Business District (CBD) is still relatively high. Therefore, it is not uncommon for people to look for residential areas in suburban areas to get cheaper prices. The widening of the residential area to the urban center edge area is often referred to as the urban sprawl phenomenon. There is a lot of understanding about urban sprawl. According to Perrsky and Wiewel (as quoted by Litynski et al., 2015), urban sprawl is the process of decentralizing population and employment from an area (city center) to its peripheral regions, accompanied by increased land use in the periphery areas. The density of residents in the city caused them to move to the suburbs.

The phenomenon of urban sprawl is related to population growth in a region. The increasing number of urban residents is accompanied by increased activity of the urban population from time to time, which also leads to an increase in the need for space. On the other hand, the availability of space in the city is fixed and limited, so the need for space for housing and the position of urban functions will take up space in the suburbs. This symptom of taking non-urban land into urban land in an unplanned and irregular manner is then what is called the urban sprawl phenomenon.

From the results of the presentation on the phenomenon of urban sprawl, can be seen in Figure 9. regarding housing product sales data in Banten, DKI Jakarta and West Java. It can be seen that the highest sales are in West Java, then Banten, and the last is DKI Jakarta in 2014 - 2018. This proves that the demand for housing in the area around DKI Jakarta is high because prices and offers for housing in DKI Jakarta have very expensive. The community prefers to become a commuter compared to having to buy housing products in DKI Jakarta.

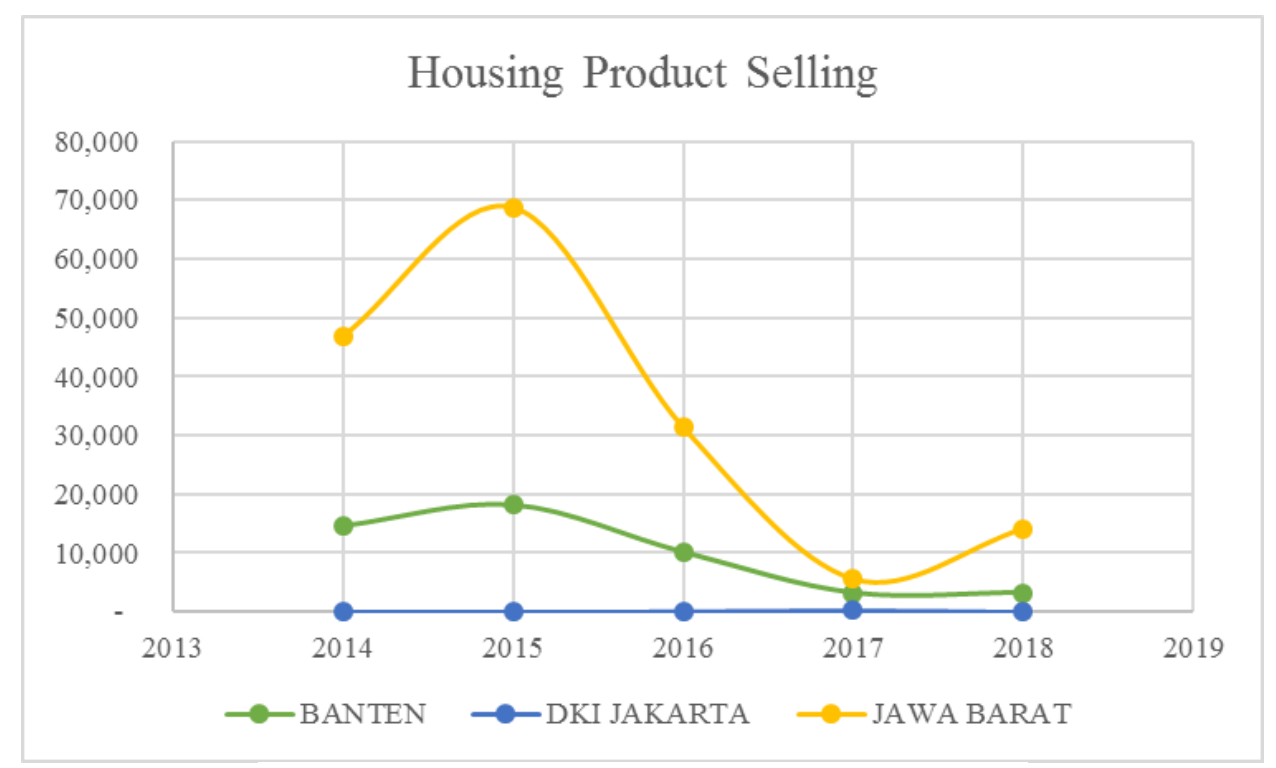

Figure 9 - Housing Product Selling (2014 - 2019) [7]

In addition, even though the one million house program has been realized, the results of interviews from PUPR said that the one million house program was not on target. The one million house program does not answer the needs of the middle-low group to have housing. Because the location of the subsidized house is far from the city center. According to Asnawi in Awaliyah (2019), the modes of transportation built by the government have not fully supported the small people. As a result, the transportation routes built by the APBN are used by the capital owners to build strategic housing for upper group.

Financial regulation held by the government is enough to help people to get housing products. Not only middle-class people, but middle and upper group are also helped by the financial regulation for the housing sector. One of the regulatory schemes issued by the government is the KPR Housing Financing Liquidity Facility (Fasilitas Likuiditas Pembiayaan Perumahan or FLPP). FLPP mortgages are intended to fulfill housing for the people. Bank Indonesia has summarized the total KPR FLPP given from 2014 - 2019 in DKI Jakarta, Banten and West Java. Figure 10. shows the total costs incurred by the government for KPR FLPP. West Java still occupies the highest position in KPR FLPP financing following the units sold in the district. 


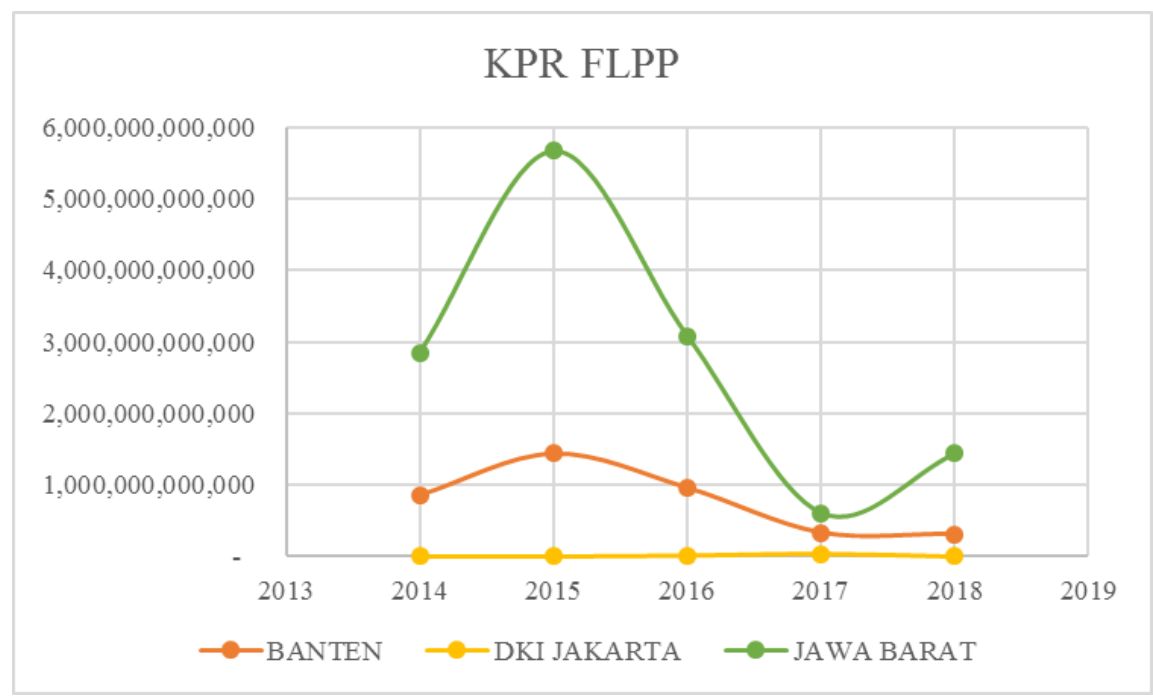

Figure 10 - KPR FLPP (2014 - 2019) [7]

Based on data submitted by Hamid in Sandy (2019), in the last four years the backlog of Indonesian home ownership has decreased by 3.2 million units. [18] This decline was one of them due to the one million home program initiated in 2015. In addition, many property businesses still complain that complicated procedures regarding licensing are still not transparent. Sandy (2019) also explained the legal case that befell Meikarta was a difficult condition. [18] The reason is, if it is not resumed it will become a no-man's concrete forest and if it continues to use whose money, while the permit has not been settled. However, in practice, the licensing process in Indonesia can take more than three months or even years.

\section{CONCLUSION}

Economic growth in Indonesia during Jokowi's tenure always increases. The increase of the economy in Indonesia is measured by GDP which continues to increase from 2014 - 2017. There are several factors that influence economic growth including income, consumption, government expenditure, and net exports. The rise of programs initiated by Jokowi 's tenure has resulted in the economy in Indonesia continuing to improve towards a better direction.

One program that was triggered in Jokowi's tenure was a program for the housing sector. There are two main programs issued to Jokowi's tenure for the housing sector. Both programs are one million houses program and FLPP KPR. Both of these programs have been initiated since the beginning of their reign in 2014. Both of these programs emerged because of the issue of housing backlogs in Indonesia. The high demand for housing products is not proportional to the existing housing product offerings. On the other hand, the supply of housing products continues to increase along with the increase in housing product prices themselves. The higher prices of housing products offered make people reluctant to buy their first home. As a result, there are still many families who occupy one house with many families or still occupy uninhabitable homes.

From the results of interviews and analysis, one million houses program is still not on target. There are still many middle-low groups who cannot yet feel a decent house at an affordable price. Whereas in this program, the government targeted the construction of a one million houses program for the middle-low group so they could enjoy their first home (to reduce the housing backlog in Indonesia, especially Jakarta).

The high price of land and the density of the city of DKI Jakarta is a factor that influences people to buy housing products around Jakarta. This phenomenon is often referred to as the urban sprawl phenomenon. The community prefers to buy a house around DKI Jakarta because of the relatively cheap price, not too densely populated, and adequate transportation to the city center. In addition, the emergence of new residential areas over time will also increase the economy in the region.

Another program published in Jokowi's tenure is KPR FLPP. The KPR FLPP scheme or subsidized KPR is quite successful for people who want to get their first home. The convenience obtained by the community when applying for the KPR FLPP is deemed sufficient to help the Indonesian people. Most KPR FLPP receivers are based on housing product selling in West Java Regency. This is also one of the justifications for the urban sprawl phenomenon. On the other hand, KPR FLPP are also profitable because the interest rates are offered regularly during the payment period with down payments being also low. So people do not have to have big capital to pay down payment to developers when buying and selling housing product transactions.

\section{Disclaimer}

The authors whose names are written certify that they have no conflict of interest. 


\section{REFERENCES}

[1] Countryeconomy.com. (2014). Indonesia GDP - Gross Domestic Product. Diambil kembali dari countryeconomy.com: https://countryeconomy.com/gdp/indonesia?year=2014

[2] Google Public Data (2018). PDB Perkapita. Diambil kembali dari Google Public Cata: https://www.google.com/publicdata/explore?ds=d5bncppjof8f9_\&met_y=ny_gdp_pcap_cd\&idim=country:IDN:PHL:LAO\&hl=id\&dl=id\#!cty

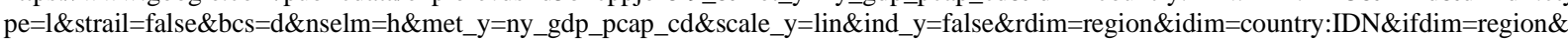
$\mathrm{hl}=\mathrm{in} \& \mathrm{dl}=\mathrm{in} \& \mathrm{in}$

[3] Trading Econommics. (2019). Indonesia Residential Property Price Index. Diambil kembali dari Trading Economics: https://tradingeconomics.com/indonesia/housing-index

[4] Badan Pusat Statistik. (2018). Produk Domestik Regional Bruto Per Kapita Atas Dasar Harga Konstan 2010 Menurut Provinsi, 2010 - 2017 (Ribu Rupiah). Diambil kembali dari Badan Pusat Statistik: https://www.bps.go.id/linkTableDinamis/view/id/958

[5] Azhar, Y. K. (2017). 10 Faktor Penentu Harga Rumah. Diambil kembali dari Housingestate.id: http://housingestate.id/read/2017/06/23/10faktor-penentu-harga-rumah/

[6] Bank Tabungan Negara. (2019). KPR BTN Subsidi. Diambil kembali dari Bank BTN: https://www.btn.co.id/id/Conventional/ProductLinks/Produk-BTN/Kredit-Konsumer/Pinjaman-Bangunan/KPR-BTN-Subsidi

[7] Bank Indonesia. (2019). Survei Harga Properti Residensial di Pasar Primer. Diambil kembali dari Bank Indonesia: https://www.bi.go.id/id/publikasi/survei/harga-properti-primer/Pages/SHPR-Tw.I-2019.aspx

[8] Al-Shareem, K., Yusof, N. A., Roosli, R. B., \& Abdullah, A.-A. (2014). PPPs as a Housing Delivery for Affordable Housing Development in Yemen. Business Management Dynamics, 03(8), 1-22.

[9] CEIC. (2019). Indonesia House Prices Growth. Diambil kembali dari CEIC: https://www.ceicdata.com/en/indicator/indonesia/house-pricesgrowth

[10] Kementerian Kesehatan Republik Indonesia. (2016). Undang-undang Lindungi Hak Anak untuk Dapatkan Pelayanan Kesehatan. Diambil kembali dari Kementerian Kesehatan Republik Indonesia: http://www.depkes.go.id/article/view/16051800001/undang-undang-lindungi-hakanak-untuk-dapatkan-pelayanan-kesehatan.html

[11] Kementerian Pekerjaan Umum dan Perumahan Rakyat. (2018). Badan Pengelola Tabungan Perumahan Segera Terbentuk Maret 2018 ini, Pemerintah Fokus Bangun Kredibilitas Lembaga. Diambil kembali dari Kementerian Pekerjaan Umum dan Perumahan Rakyat: https://www.pu.go.id/berita/view/15342/mohon-maaf-layanan-email-kementerian-pupr-akan-terganggu-karena-adanya-update-server-padahari-rabu-26-juni-2019-pkl-18-00-wib-s-d-pkl-22-00-wib\#

[12] Kinanti, K. P. (2019). BP Tapera Dilantik, Program Tabungan Perumahan Segera Terealisasi. Diambil kembali dari Ekonomi: https://ekonomi.bisnis.com/read/20190331/47/906435/bp-tapera-dilantik-program-tabungan-perumahan-segera-terealisasi

[13] Kominfo. (2016). Paket Kebijakan Ekonomi XIII: Rumah Murah Untuk Rakyat. Diambil kembali dari Kominfo: https://www.kominfo.go.id/content/detail/7936/paket-kebijakan-ekonomi-xiii-rumah-murah-untuk-rakyat/0/berita

[14] Kurniawan, I., \& Purwono, R. (2017). Property Price Bubble: Regional Analysis in Indonesia. Journal of Developing Economics, 02(1), 1-11.

[15] Otoritas Jasa Keuangan. (2019). Suku Bunga Dasar Kredit. Diambil kembali dari Otoritas Jasa Keuangan: https://www.ojk.go.id/id/kanal/perbankan/Pages/Suku-Bunga-Dasar.aspx

[16] Pusat Pengelolaan Dana Pembiayaan Perumahan. (2019). Syarat Penerima. Diambil kembali dari Pusat Pengelolaan Dana Pembiayaan Perumahan: http://ppdpp.id/syarat/

[17] Rosa, Y. (2013). Rumusan Metode Perhitungan Backlog Perumahan. Jurnal Permukiman, 8(2), 58-68.

[18] Sandy, K. F. (2019). Backlog Perumahan Sudah Berkurang 3,2 Juta Unit. Diambil kembali dari Sindonews.com: https://ekbis.sindonews.com/read/1352730/179/backlog-perumahan-sudah-berkurang-32-juta-unit-1541596175

[19] Badan Pusat Statistik. (2018). Ketimpangan Hidup di DKI Jakarta di atas Rata-rata Nasional. Diambil kembali dari Katadata.co.id: https://databoks.katadata.co.id/datapublish/2018/07/05/ketimpangan-di-dki-jakarta-di-atas-rata-rata-nasional

[20] Vajiranivesa, P. (2008). A Housing Demand Model: A Case Study of The Bangkok Metropolitan Region, Thailand. RMIT University, 1-9.

[21] Wedhaswary, I. (2014). "Nawa Cita", 9 Agenda Prioritas Jokowi-JK. Diambil kembali dari Kompas: https://nasional.kompas.com/read/2014/05/21/0754454/.Nawa.Cita.9.Agenda.Prioritas.Jokowi-JK

[22] Widjanarko, O. (2019). BI 7-Day Reverse Repo Rate Held at 6,00\%: Strengthening External Stability, Maintaining Economic Growth Momentum . Diambil kembali dari Bank Indonesia: https://www.bi.go.id/en/ruang-media/siaran-pers/Pages/SP_211719.aspx

[23] World Bank. (2019). GDP Growth (annual \%). Diambil kembali dari The World Bank: https://data.worldbank.org/indicator/NY.GDP.MKTP.KD.ZG?end=2017\&locations=ID\&start=2014 